\title{
Synthesis of Heteroarylferrocenes by Friedländer Reaction and Their Spectral Properties
}

\author{
Woo Jin Lee, Jong Myoung Chea, and Yumgdong Jahng-

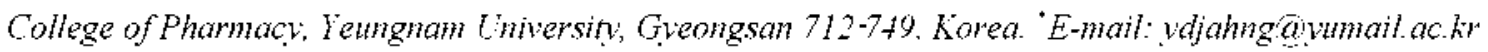 \\ Received September 2, 2009, Accepted October 24, 2009
}

\begin{abstract}
A series of mono-and 1,1'-bis(heteroaryl)-substituted ferrocenes were prepared by employing Frieländer reaction of acetyl-and $1, l^{\prime}$-diacetylferrocene with a series of $o$-aminoaldehydes. Reactions of $1, l^{\prime}$-diacetylferrocene with two equivalents of 1 -aminonaphthalene-2-carbaldehyde and 8-aminoquinoline-7-carbaldehy de afforded a mixture of mono-and $1, l^{\prime}$-bis(heteroary 1 )-substituted ferrocenes in a ratio of $1: 3.1-3.8$, while the reaction with 4-aminoacridine3-carbaldehy'de did not provide any characterizable product presumably due to the redox instability of the product induced by low reduction potential of benzo $[b]-1,10$-phenanthroline. Structural and optical properties of the compounds prepared were described.
\end{abstract}

Key Wonds: Ferrocene. Benzo $[h]$ quinoline, 1,10-Phenanthroline, Benzo[b]-1,10-phenanthroline. Heteroarylferrocene

\section{Introduction}

Ferrocene ${ }^{1}$ is an aromatic compound in which two cyclopentadienyl ( $\mathrm{Cp}$ ) anions form covalent bonds to ferrous iron symmetrically ${ }^{2}$ and possesses a low rotational barrier ${ }^{3}$ which enables to interconvert $s, n$ and $a n t i$ isomers of a 1.1 '-disubstituted derivative (Figure 1) thus showing excellent mobility about the organometallic bond.

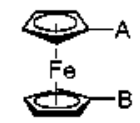

syn-isomer

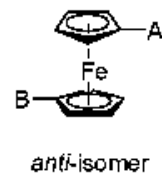

In the case that substituents $\mathrm{A}$ and $\mathrm{B}$ are plantar aromatic species. however, rotation about the $\mathrm{A} / \mathrm{B}-\mathrm{Cp}$ bond becomes important. Although an $a n t i$-isomer is expected to be the major. proton resonances of 1,1'-diaryl-substituted ferrocenes ${ }^{4}$ (aryl $=$ phenyl. I'-naphthỵl or 4-biphenylyl) are upfield shifted compared to those of monoaryl-substituted ferrocenes to suggest that the 1 . I'-diaryl-substituted ferrocenes retain a stn geometry. Similarly studies" on ${ }^{\mathrm{l}} \mathrm{H}$ NMR spectra of a series of mono- and bis-heteroaryl ferrocenes support that two heteroaromatic rings are coplanar with their adjacent $\mathrm{Cp}$ ring. The single-crystal $\mathrm{X}$-ray analysis of 1,1'-bis[2-(8-methosyquinolyl)] ferrocene additionally confirms two quinoline rings are pointing in opposite direction, with their pyridine moieties partially overlapped.

However, the substituents at $\mathrm{C} 3$ position of the heteroaryls would impose an increase of dihedral angle between $\mathrm{Cp}$ and heteroaryl rings to lead inhibition against rotation about the organometallic bond. Musso and co-workers have shown that when the $\mathrm{Cp}$ is perpendicular to the aryl substituent. $\pi$-stacking does not occur and the diarylferrocene adopts an anti conformation.

The ferrocene moiety not only plays a significant role as backbone or an ancillary substituent in ligands due to the unique structure but also has potential application in material science especially in așymmetric catalỵsis and molecular devices and electronic sensors due to the redox-active properties of such ligands. ${ }^{9}$ Even though interest in ferrocene chemistry is increasing. numbers of heteroanylferrocenes are somewhat limited. ${ }^{1 i}$

Our interest ${ }^{13}$ in the preparation and properties of polydentates spurred to prepare a series of 1-heteroaryl- and 1, 1 di(heteroaryl)ferrocenes and to study their properties.

\section{Expelimental Section}

Melting points were determined using a Fischer-Jones melting points apparatus and are not corrected. IR spectra were obtained using a Perkin-Elmer 1330 spectrophotonteter. NMR spectra were obtained using a Bruker-250 spectrometer 300 $\mathrm{MHz}, 400 \mathrm{MHz}$ or $600 \mathrm{MHz}$ for ${ }^{\mathrm{H}} \mathrm{H} \mathrm{NMR}$ and $75 \mathrm{MHz}, 100$ $\mathrm{MHz}$, and $150 \mathrm{MHz}$ for ${ }^{13} \mathrm{C}$ NMR and are reported as parts per million (ppm) from the internal standard tetramethylsilane (TMS). The starting $o$-aminoaldehydes $(2)^{12}$ were prepared by employing previously reported methods. Chemicals and solvents were conmercial reagent grade and used without further purification. Electrospray ionization (ESI) mass spectrometry (MS) experiments were performed on a LCQ advantage-trap mass spectrometer (Thermo Finnigan San Jose. CA, USA). Elemental analyses were taken on a Hewlett-Packard Model $185 \mathrm{~B}$ elemental analyzer. Abbreviations bq. phen, and bphen were introduced for benzo $[h]$ quinoline. 1,10-phenanthroline. and benzo[b]-1,10-phenantluroline, respectively.

2-(Femocenyl)benzo[ $h]$ quinoline (3a) (Genemal Procedure). To a mixture of 8-aminoquinoline-7-carbaldehyde (133 $\mathrm{mg}$. $1.10 \mathrm{mmol}$ ) and 1 -acetylferrocene $(358 \mathrm{mg} .1 .00 \mathrm{mmol}$ ) in absolute EtOH (20 mL) was added saturated alcoholic $\mathrm{KOH}$ $(1 \mathrm{~mL}$ ). The resulting mixture was refluxed for $5 \mathrm{~h}$. Upon cooling the reaction mixture, a yellow solid was formed which was collected (389 mg. 88\%): mp 181 'C. IR (KBr) v 3056. 1593. 1445. $1429.824 \mathrm{~cm}^{-1}$. ${ }^{l} \mathrm{H}$ NMR $\left(\mathrm{CDCl}_{3}, 250 \mathrm{MHz}\right) \delta 9.42$ (d. $J=8.0 \mathrm{~Hz}, \mathrm{lH} . \mathrm{Hl} 0 \mathrm{of} \mathrm{bq).8.05}$ (d. $J=8.5 \mathrm{~Hz} . \mathrm{lH} . \mathrm{H} 4$ of bq). 7.90 (d. $J=8.0 \mathrm{~Hz}, 1 \mathrm{H} . \mathrm{H} 7$ of bq). $7.76(\mathrm{~d} . J=8.5 \mathrm{~Hz} .1 \mathrm{H}$, $\mathrm{H} 5 / \mathrm{H} 6$ of bq). 7.73 (td. $J=8.0,1.3 \mathrm{~Hz}, \mathrm{lH} . \mathrm{H} 9$ of bq) .7 .71 (td. $J=8.0,1.3 \mathrm{~Hz}, 1 \mathrm{H}, \mathrm{H} 8$ of bq), 7.64 (d. $J=8.5 \mathrm{~Hz}$. $2 \mathrm{H}$. H3 
and $\mathrm{H} 6 / \mathrm{H} 5$ of bq). 5.18 (d. $J=1.8 \mathrm{~Hz} .2 \mathrm{H}$. Ha and $\mathrm{H \alpha}$ ), 4.48 (t. $J=1.8 \mathrm{~Hz}, 2 \mathrm{H}, \mathrm{H} \beta$ and $\mathrm{H} \beta$ ) .4 .07 (br s. $5 \mathrm{Cp}-\mathrm{H}$ ). ${ }^{13} \mathrm{C} \mathrm{NMR}$ $\left(\mathrm{CDCl}_{3}\right) \delta 158.02 .146 .06 .135 .41 .133 .83,131.45,127.87$. $127.63,126.56 .126 .30 .125 .32 .124 .66 .124 .17 .119 .18 .84 .34$. 70.19.69.64.67.85. MS (ESI) calcd for $\mathrm{C}_{33} \mathrm{H}_{18} \mathrm{FeN}[\mathrm{M}+\mathrm{H}]^{+}$: 364. Found: 364. Elemental Analy sis: Calcd for $\mathrm{C}_{23} \mathrm{H}_{1}=\mathrm{FeN}$ : C. 76.05: H. 4.72: N. 3.86. Found: C. 76.17: H. 4.75 N. 3.76.

2-(Femocenyl)-1,10-phenathroline (3b). Yellow needles (86\%): mp $198^{\circ} \mathrm{C}$. 'H NMR (CDCl $\left..250 \mathrm{MHz}\right)$ ô 9.17 (d. $J=$ $4.8 \mathrm{~Hz}, \mathrm{IH}, \mathrm{H} 9$ of bq) 8.19 (d. $J=7.8 \mathrm{~Hz}, 1 \mathrm{H} . \mathrm{H}+$ of bq) 8.09 (d. $J=8.3 \mathrm{~Hz} .1 \mathrm{H} . \mathrm{H} 7$ of bq), 7.81 (d. $J=8.5 \mathrm{~Hz}$. H3 of bq), $7.70(2 \mathrm{H}, \mathrm{AB}$ quartet. $\mathrm{H} 5$ and $\mathrm{H} 6$ of bq) 7.57 (dd. $J=8.0 .4 .8$ Hz. $\mathrm{H} 8$ of bq), 5.22 (brs. $2 \mathrm{H}$. Ha and $\mathrm{H} \alpha^{\prime}$ ). 4.46 (br s, $2 \mathrm{H}, \mathrm{H \beta}$ and $\mathrm{H} \beta$ ) 4.03 (br s. $5 \mathrm{Cp}-\mathrm{H}$ ). ${ }^{13} \mathrm{C} \mathrm{NMR}\left(\mathrm{CDCl}_{3}\right)$ ò 160.53 . 150.53, 146.40, 146.27, 136.42. 135.93. 129.47, 127.16. 126.97. $125.59 .123 .00,121.72,84.62,70.76 .70 .09,69.08$. MS (ESI) calcd for $\mathrm{C}_{22} \mathrm{H}_{1}: \mathrm{FeN} \mathrm{N}_{2}[\mathrm{M}+\mathrm{H}]^{-}: 365$. Found: 365.

2-(Femoceny])benzo[b]-1,10-phenathroline (3c). Pale yellow needles (83\%): $\operatorname{mp} 215^{\circ} \mathrm{C} .{ }^{1} \mathrm{H} N M R\left(\mathrm{CDCl}_{3}, 250 \mathrm{MHz}\right) \delta 9.76$ (s, 1H. H7 of bq). 8.60 (d. $J=8.5 \mathrm{~Hz}, 1 \mathrm{H}$. H1 1 of bq), 8.12 (d. $J=8.3 \mathrm{~Hz} .1 \mathrm{H} . \mathrm{H}+$ of bq). $8.05(\mathrm{dd}, J=8.3 .1 .0 \mathrm{~Hz} .1 \mathrm{H}, \mathrm{H} 8$ of bq) .7 .87 (td $J=8.0 .1 .0 \mathrm{~Hz}$. H9 of bq). 7.83 (d. $J=9.0 \mathrm{~Hz}$. $\mathrm{H} 5 / \mathrm{H} 6$ of bq), 7.66 (d. $J=9.0 \mathrm{~Hz} . \mathrm{H} 6 / \mathrm{H} 5$ of bq), 7.63 (td. $J=$ $8.0 .1 .0 \mathrm{~Hz}$. Hl0 of bq) 7.55 (d. $J=8.0 \mathrm{~Hz} . \mathrm{H} 3$ of bq) 5.18 (d. $J=1.8 \mathrm{~Hz} .2 \mathrm{H}$. Ha and $\left.\mathrm{H \alpha}^{\prime}\right), 4.48(\mathrm{t}, J=1.8 \mathrm{~Hz} .2 \mathrm{H}$. $\mathrm{H \beta}$ and $\mathrm{H} \beta$ ) 4.07 (br s. $5 \mathrm{Cp}-\mathrm{H}$ ). ${ }^{13} \mathrm{C} \mathrm{NMR}\left(\mathrm{CDCl}_{3}\right)$ o 157.08 . 148.10, 146.67, 146.04, 136.11, 135.67. 130.96, 129.70. 127.42. $127.17,127.08 .126 .75 .126 .52 .125 .92 .125 .75 .124 .03 .79 .05$. $72.24,69.73 .69 .46 . \mathrm{MS}$ (ESI) calcd for $\mathrm{C}_{26} \mathrm{H}_{29} \mathrm{FeN} 2[\mathrm{M}+\mathrm{H}]^{+}$: 425. Found: 425 . Elemental Analysis: Calcd for $\mathrm{C}_{26} \mathrm{H}_{28} \mathrm{FeN}_{2}$ : C. $73.59:$ H. 6.65: N. 6.60. Found: C. $73.72:$ H. 6.58: N. 6.59 .

1,1'-Bis(benzo[ $h]$ quinolin-2-yl)femocene (5a). To a solution of $1, \mathrm{l}^{\prime}$-diacetylferrocene ( $100 \mathrm{mg} .0 .37 \mathrm{mmol}$ ) and 8-aminoquinoline-7-carbaldehỵde ( $140 \mathrm{mg} .0 .81 \mathrm{mmol}$ ) in EtOH (10 $\mathrm{mL}$ ) was added saturated alcoholic $\mathrm{KOH}(0.1 \mathrm{~mL})$. Resulting mixture was refluxed for $8 \mathrm{~h}$. Evaporation of the solvent gave a solid material which was chromatographed on silica gel eluting with $\mathrm{CH}_{2} \mathrm{Cl}_{2}$ : hexane $(1: 1)$. The early fractions $\left(R_{\mathrm{f}}=0.85\right)$ afforded $30 \mathrm{mg}(20 \%)$ of 2-(2-ferrocenyl)benzo[ $h]$ quinoline (3a): $m p 181^{\circ} \mathrm{C}$. of which the spectral data were identical to those described above for $3 \mathrm{a}$. The latter fractions $\left(R_{\mathrm{f}}=0.80\right)$ afforded $150 \mathrm{mg}(75 \%)$ yellow solid as 1.1 '-bis(benzo $[h]$ quinolin-2-yl)ferrocene: $\operatorname{mp} 219^{\circ} \mathrm{C}(\mathrm{EtOH}) .{ }^{1} \mathrm{H}$ NMR $(600 \mathrm{MHz}$. $\left.\mathrm{CDCl}_{3}\right) \delta 9.01(\mathrm{dd}, J=8.8 .2 .0 \mathrm{~Hz} .2 \mathrm{H}, \mathrm{HlO}$ of bq), $7.77(\mathrm{dd}$, $J=8.0,1.8 \mathrm{~Hz}, 2 \mathrm{H}, \mathrm{H} 7$ of bq) 7.60 (td. $2 \mathrm{H} . J=7.0 .2 .5 \mathrm{~Hz}$. H9). 7.53 (td. $2 \mathrm{H}, J=7.0,2.5 \mathrm{~Hz}, \mathrm{H9}$ ). 7.47 (d. $J=8.8 \mathrm{~Hz}, 2 \mathrm{H}$. $\mathrm{H} 4$ of bq), 7.09 (AB quartet. $4 \mathrm{H}$. $\mathrm{H} 5$ and $\mathrm{H} 6$ of bq). 7.00 (d, $J=8.8 \mathrm{~Hz}, 2 \mathrm{H}, \mathrm{H} 3$ of bq). $5.13\left(\mathrm{~d}, J=1.8 \mathrm{~Hz}, 2 \mathrm{H} . \mathrm{H \alpha}\right.$ and $\left.\mathrm{H}^{\circ}\right)$. $4.47\left(\mathrm{t} . J=1.8 \mathrm{~Hz}, 2 \mathrm{H}, \mathrm{H \beta}\right.$ and $\mathrm{H} \beta$ ) ${ }^{13} \mathrm{C} \mathrm{NMR}\left(\mathrm{CDCl}_{3}\right)$ ô 154.97 , $145.52,134.70,133.53,131.02,127.51,127.37,126.06,125.77$. $124.98 .124 .57,123.62 .118 .66 .85 .94,70.82,68.81$. MS (ESI) calcd for $\mathrm{C}_{36} \mathrm{H}_{25} \mathrm{FeN}_{2}[\mathrm{M}+\mathrm{H}]^{+}: 541$. Found: 541 . Elemental Analysis: Calcd for $\mathrm{C}_{36} \mathrm{H}_{24} \mathrm{FeN}_{2}$ : C. 80.0I: $\mathrm{H}, 4.48:$ N. 5.18 . Found: C. 79.87: H, 4.55: N, 5.22.

1,1'-Bis $(1,10$-phenanthrolin-2-yl)fenocene (5b). Reaction nixture obtained was chromatographed on alumina eluting with $\mathrm{CH}_{2} \mathrm{Cl}_{2}$. The early fractions $\left(R_{\mathrm{f}}=0.5\right)$ afforded $20 \mathrm{mg}$ $(21 \%)$ of orange needles: mp $198^{\circ} \mathrm{C}$, of which the spectral data were identical to those described above for $\mathbf{3 b}$. The latter fractions $\left(R_{\mathrm{f}}=0.3\right)$ afforded $\mathbf{5 b}$ as pale orange needles $(65 \%)$ : $230{ }^{\circ} \mathrm{C}$. ${ }^{l} \mathrm{H}$ NMR $\left(250 \mathrm{MHz} . \mathrm{CDCl}_{3}\right) \delta 9.14(\mathrm{dd}, 2 \mathrm{H}, J=4.3$, $1.8 \mathrm{~Hz} . \mathrm{H} 9$ of phen). 8.16 (dd. $2 \mathrm{H} . J=7.8,1.2 \mathrm{~Hz}, \mathrm{H} 7$ of phen). 7.56 (dd. $2 \mathrm{H} . J=7.5,4.2 \mathrm{~Hz}$. $\mathrm{H} 8$ of phen). 7.54 (d. $2 \mathrm{H} . J=8.4$ $\mathrm{Hz}$. $\mathrm{H} 4$ of phen) 7.30 (d. $2 \mathrm{H} . J=8.4 \mathrm{~Hz}$. $\mathrm{H} 5$ of phen). $7.2 \mathrm{I}$ (d. $2 \mathrm{H}, J=8.4 \mathrm{~Hz}$. $\mathrm{H} 6$ of phen). 7.15 (d. $2 \mathrm{H}, J=8.4 \mathrm{~Hz} . \mathrm{H} 3$ ). 5.28 (t. $4 \mathrm{H}, J=1.8 \mathrm{~Hz}$. Ha of Cp), $4.48(\mathrm{t},+\mathrm{H} . J=1.8 \mathrm{~Hz}, \mathrm{H} \beta$. of $\mathrm{Cp}$ ). ${ }^{\mathrm{j}} \mathrm{H} \mathrm{NMR}\left(600 \mathrm{MHz}, \mathrm{CDCl}_{3}\right.$, with $5 \mathrm{mg}$ of isoascorbic acid) $\delta$ 9.11 (dd. $2 \mathrm{H} . J=4.2 .1 .2 \mathrm{~Hz}$. $\mathrm{H} 9$ of phen), 8.17 (dd, $2 \mathrm{H} . J=$ $8.0 .1 .8 \mathrm{~Hz} . \mathrm{H} 7$ of phen). 7.55 (dd. $2 \mathrm{H}, J=7.5 .4 .8 \mathrm{~Hz} . \mathrm{H} 8$ of phen). $7.54(\mathrm{~d}, 2 \mathrm{H}, J=8.4 \mathrm{~Hz}, \mathrm{H}+$ of phen). $7.30(\mathrm{~d}, 2 \mathrm{H}, J=$ $9.0 \mathrm{~Hz}$. H6 of phen). 7.20 (d. $2 \mathrm{H} . J=9.0 \mathrm{~Hz}$. H3 of phen). 7.16 (d. $2 \mathrm{H}, J=8.4 \mathrm{~Hz}, \mathrm{H} 5$ of phen), 5.24 (t. $4 \mathrm{H}, J=1.8 \mathrm{~Hz}, \mathrm{H \alpha}$ of

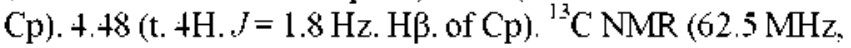
$\left.\mathrm{CDCl}_{3}\right) \hat{\delta}$ 157.73. 149.86. 1+6.13. 145.72. 135.68. 135.00. 128.80. 126.37. 126.32. 124.66, 122.36. 121.02.85.99. 71.16,69.81. MS (ESI) calcd for $\mathrm{C}_{34} \mathrm{H}_{33} \mathrm{FeN}_{4}[\mathrm{M}+\mathrm{H}]^{-}: 543$. Found: 543 .

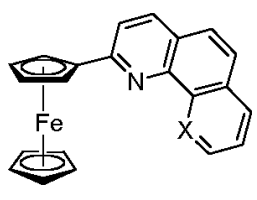

$3 \mathrm{a} X=\mathrm{CH}$ $b X=N$

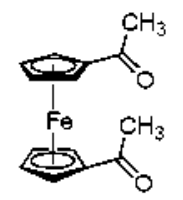

1b
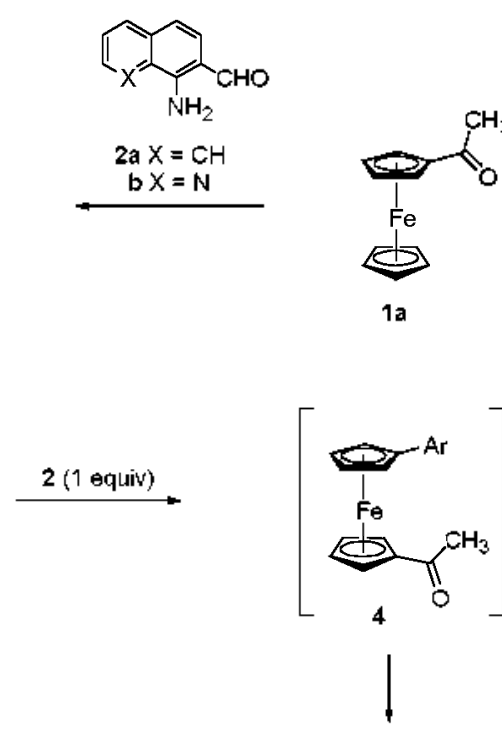

3a,b
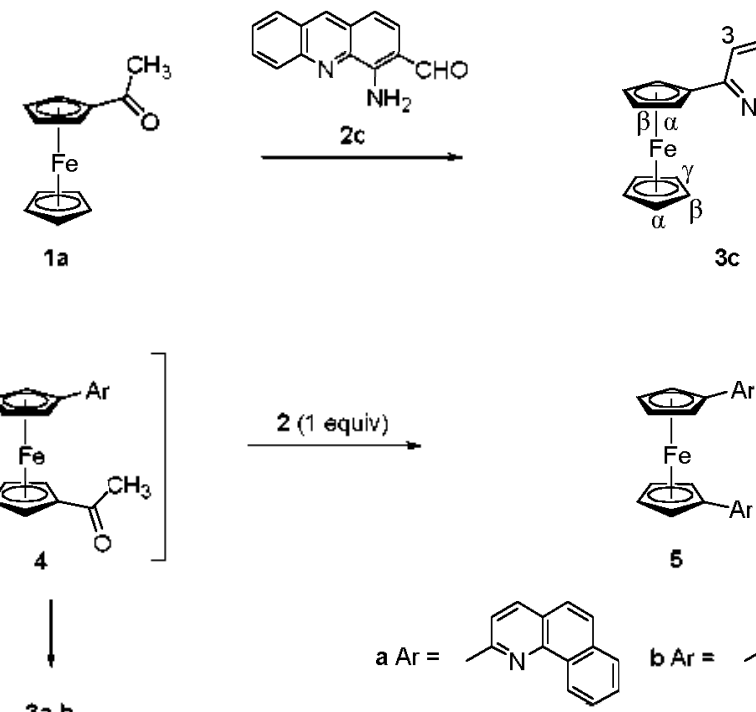

b $\mathrm{Ar}=$

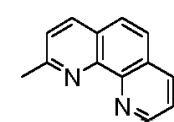




\section{Results and Discussion}

Preparation of the ferrocene-derived ligands is straight forward as shown in Scheme 1. The Friedländer condensation of acety'lferrocene (1a) ${ }^{13}$ with a series of $o$-aminoaldehydes (2) afforded the corresponding monoheteroarylferrocenes $(3)$ in $83 \sim 88 \%$ yields. On the other hand reaction of 1 . 1 '-diacetylferrocene ( $\mathbf{1 b})^{\text {t4 }}$ with 2.2 equivalents of 2 afforded a mixture of 1.1'-bis(heteroaryl)ferrocenes (5) and mono-condensed 2(ferrocenyl)heteroaromatics (3), which were readily separable by column chromatography. Surprisingly. reaction of $1 \mathrm{~b}$ with 2 afforded 1. I'-bis(2-heteroaryl)ferrocene (5) and unexpected 2 -(ferrocenyl)heteroaromatics (3) instead of expected 1 -acetyl$1^{*}$-(2-heteroaryl)ferrocenes (4) in a ratio of $3.1: 1$. Formation of 3 from 1 b and 2 could be explained by base-catalyzed deacetylation of acetylaromatics (4). An initial equimolar condensation of $\mathbf{1 b}$ and 2 would afford 4 . which were then undergone either Friedländer condensation with additional 2 to lead the desired compounds 5 or base-catalyzed deacetylation to afford 3 as had been reported previously. ${ }^{15}$ Attempts for the condensation of $\mathbf{1 b}$ with $\mathbf{2 c}$ were failed to afford either biscondensed one or mono-condensed 3c. but instead as yet unidentifiable black solid. Although we can not explain clearly, reduction potentials of the heteroaromatics may affect the stability of the compounds. We reasoned that the half-way reduction potential $(-1.52 \mathrm{~V} v s \mathrm{SCE})$ of benzo[b]-1.10-phenanthroline is much lower than those of benzo[h]quinoline $(-2.23 \mathrm{~V})^{16}$ and 1.10 -phenanthroline $(-2.12 \mathrm{~V}){ }^{16}$ which implies that benzo $[b]$ 1.10-phenanthroline nucleus is the better electron acceptor and thus more readily reduced than 1,10-phenanthroline and benzo $[h]$ quinoline. Such a potential would affect the stability of Fe(II) ion in ferrocene moiety to oxidize Fe(II) to Fe(III). Similar redox-instability of Fe(II) ion was also observed in 5b. Reduction potentials of the two 1,10-phenantholines are enough to lead at least partial oxidation of $\mathrm{Fe}$ (II) yielding paramagnetic Fe(III) species. thus fail to provide a good ${ }^{1} \mathrm{H}$ NMR spectrum of $\mathbf{5 b}$ at either room temperature or even lower temperature $\left(-43^{\circ} \mathrm{C}\right)$. The addition of isoascorbic acid $(\sim 3 \mathrm{mg})$ as a reducing agent in ${ }^{\mathrm{l}} \mathrm{H}$ NMR sample tube ${ }^{1 \text { " }}$ stabilizes $\mathrm{Fe}$ (II) species to result a well-resolved spectrum (Supporting Information).
It should be noted that (1.10-phenanthrolin-2-yl)ferrocene (3b) and 1, l'-bis (1.10-phenanthrolin-2-yl)-ferrocene (5b) were prepared in $20 \sim 35 \%$ and $14 \%$ yield. respectively, by the direct reactions of monolithio- and dilithioferrocenes with 1.10 phenanthroline. ${ }^{18 a}$ Above reaction was modified by subsequent oxidation of addition adducts with strong oxidizing agent such as DDQ to improve the corresponding y ields to $80 \%$ and $65 \%$. respectively. ${ }^{8}$ Attempts to prepare 1, 1'-bis(benzo $[b]$ 1.10-phenanthrolin-2-yl)ferrocene from dilithioferrocene and benzo $[b]-1.10$-phenanthroline ${ }^{19}$ were also failed.

Some proton resonances of heteroaryl moieties were characteristic enough to afford a probe for the structure suggested. The H10 of 2-substituted benzo[h]quinoline ( $3 a$ and 5 a) is experiencing deshielding effect of $\mathrm{Nl}$ and thus the most downfield shifted resonance in the system. while $\mathrm{H} 9$ of 1.10-phenanthroline ( $\mathbf{3 b}$ and $\mathbf{5 c}$ ) is the one of characteristic chemical shifts with relatively small ${ }^{3} J$ coupling constants $\left({ }^{3} J=4-5\right.$ $\mathrm{Hz}) .^{20}$ Similarly $\mathrm{H} 1 \mathrm{l}$ of benzo $[b]-1.10$-phenanthroline (3c) is parallel to the lone pairs of electrons of nitrogen at the periposition to show characteristic chemical shifts in the region of $\delta 8.60-8.60^{11,18}$ In addition the resonances of $\alpha$-protons at the substituted $\mathrm{Cp}$ moiety generally appeared in the region of $\delta 5.18 \cdot 5.24$ due to the deshielding effect of nitrogen as two triplets with a characteristically small coupling constant $\left({ }^{3} J=\right.$ $1.8 \cdot 2.3 \mathrm{~Hz}$ ) while $\beta$-protons ô $4.44 \cdot 4.48$. Protons of unsubstituted $\mathrm{Cp}$ ring are generally resonanced in the range of $\delta$ $4.03-4.07$.

The 1,1 '-bis(heteroaryl)ferrocenes may have three possible conformations as shown in Figure 2. The proton resonances of mono- and bis-heteroarylferrocenes may afford information for the conformation. All the proton resonances of bis(heteroaryl)ferrocenes are upfield shifted as compared to the analogous resonances of the mono-substituted ferrocenes $\mathbf{3}$ as has been reported previously for 1, I'-bis(aryl)ferrocenes. which excludes the possible anti-isomer ( $\mathrm{C}$ in Figure 1 ). The magnitudes of the shift are highly dependent on the protons (Table 1). Protons of $\mathrm{H} 3 . \mathrm{H} 4 . \mathrm{H} 5$. and $\mathrm{H} 6$ of the 1, 1'-bis(2-heteroaryl) ferrocenes are the most upfield-shifted ones by $0.42-0.64$ ppm due to the anisotropic effect of the neighboring heteroaryl groups while the rest were upfield-shifted only by 0.02 $0.14 \mathrm{ppm}$ except $\mathrm{HIO}$ which was shifted by $0.41 \mathrm{ppm}$. Such

Table 1. 'H NMR Chemical Slift Data for Heteroary l-Substituted Ferrocenes

\begin{tabular}{|c|c|c|c|c|c|c|c|c|c|c|c|c|}
\hline \multirow{2}{*}{ Connd } & \multicolumn{9}{|c|}{ heteroaryl protons } & \multicolumn{3}{|c|}{ ferrocene protons } \\
\hline & $\mathrm{H} 3$ & $\mathrm{H} 4$ & $\mathrm{H} 5$ & $\mathrm{H} 6$ & $\mathrm{H} 7$ & $\mathrm{H} 8$ & $\mathrm{H} 9$ & $\mathrm{HlO}$ & HIl & $\mathrm{H} \alpha$ & $\mathrm{H} \beta$ & $\mathrm{H} \gamma$ \\
\hline $3 a$ & 7.64 & 8.05 & $7.76^{a}$ & $7.64^{a}$ & 7.90 & 7.71 & 7.73 & 9.42 & - & 5.18 & 4.48 & 4.07 \\
\hline $5 \mathfrak{a}$ & 7.03 & 7.50 & 7.12 & 7.12 & 7.78 & 7.57 & 7.61 & 9.01 & - & 5.13 & 4.47 & - \\
\hline$\Delta \hat{\delta}$ & $(0.61)$ & $(0.55)$ & $(0.64)$ & $(0.52)$ & $(0.12)$ & $(0.14)$ & $(0.12)$ & $(0.41)$ & - & $(0.05)$ & $(0.01)$ & - \\
\hline $3 b$ & 7.81 & 8.09 & 7.70 & 7.70 & 8.19 & 7.57 & 9.18 & - & - & 5.22 & 4.46 & 4.03 \\
\hline $\mathbf{5 b}$ & 7.20 & 7.34 & 7.11 & 7.28 & 8.17 & 7.55 & 9.11 & - & - & 5.24 & 4.44 & - \\
\hline$\Delta \bar{y}$ & $(0.61)$ & $(0.45)$ & $(0.59)$ & $(0.42)$ & $(0,02)$ & $(0.02)$ & $(0.07)$ & - & - & & & - \\
\hline $3 c$ & 7.55 & 8.12 & 7.83 & 7.66 & 9.76 & 8.05 & 7.87 & 7.63 & 8.60 & 5.18 & 4.48 & 4.07 \\
\hline $\mathbf{Q F}$ & 7.56 & 8.03 & 7.74 & 7.45 & 7.66 & 8.04 & - & - & - & 5.07 & 4.47 & 4.06 \\
\hline $\mathbf{B Q F}$ & 6.98 & 7.19 & 7.40 & 7.38 & 7.58 & 7.86 & - & - & - & 5.05 & 4.43 & - \\
\hline$\Delta \tilde{\delta}$ & $(0.58)$ & (0.84) & (0.34) & $(0.07)$ & $(0.08)$ & $(0.18)$ & - & - & - & $(0.02)$ & $(0.04)$ & - \\
\hline
\end{tabular}

"Assignment can be reversed. $\mathrm{QF}$ and $\mathrm{BQF}$ are the abbreviations of (2-quinolyl)ferrocene and $1.1^{2}$-bis(2-quinolyl)ferrocene. respectively. 
Table 2. Absorption and Emission Spectral Data of Heteroaryl-Substituted Ferrocenes

\begin{tabular}{|c|c|c|c|c|c|c|c|c|}
\hline Compound & & & $\lambda_{\max },(95 \%$ & $\mathrm{EtOH})\left(\varepsilon \mathrm{M}^{1}\right.$ & $\left.m^{-1}\right)$ & & & $\lambda_{\text {emmlssson }}$ \\
\hline Femocene & $240(3,500)$ & $265(1,600)$ & $325(50)$ & $440(100)$ & & & & \\
\hline $3 a$ & $238(12,500)$ & $268(4,700)$ & $290(5,700)$ & $305(4,000)$ & $315(3,500)$ & $447(320)$ & & $396,417,440$ (sh) \\
\hline $3 b$ & $231(11,700)$ & $267(7,400)$ & $370(1,100)$ & $447(320)$ & & & & 420 \\
\hline $3 c$ & $223(8,000)$ & $257(12,600)$ & $290(6,600$, sh $)$ & $302(8,300)$ & $316(6,000)$ & $380(50)$ & $460(80)$ & 510 \\
\hline $5 a$ & $237(13,100)$ & $278(69,000)$ & $305(5,900)$ & $370(160)$ & & & & $408,440(\mathrm{sh})$ \\
\hline $5 \mathbf{b}$ & $232(15,900)$ & $269(10,000)$ & $307(4,100)$ & $326(70)$ & & & & 425 \\
\hline
\end{tabular}

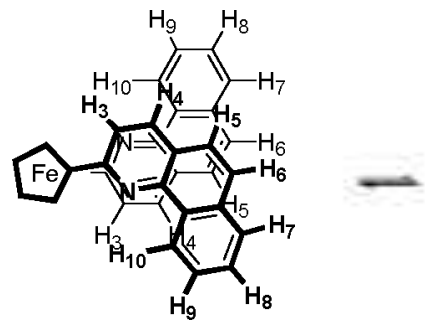

Conformation A

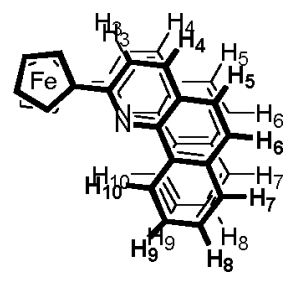

Conformation B

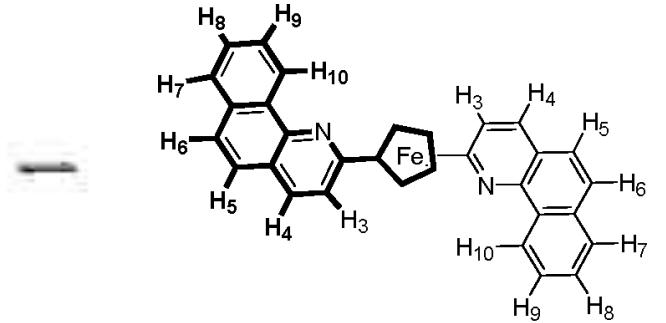

Conformation C

Figure 1. Conformational pictures of 5 a derived from ${ }^{\text {H }} \mathrm{H}$ NMR data.

anisotropic effect would not affect very much for $\mathrm{H} 7, \mathrm{H} 8$ and $\mathrm{H} 9$. which excluded the possible conformation B in Figure 1. Such a difference in the magnitude of shift suggests that two heteroaryl rings are pointing in opposite direction. with their pyridine moieties partially overlapped as shown in Figure 1 (conformation A).

UV absorption spectra of mono- (3) and I. l'-disubstituted ferrocenes (5) were taken from $\mathrm{CH}_{3} \mathrm{CN}\left(6.25 \times 10^{-5} \mathrm{M}\right)$ and are summarized in Table 2 . UV spectrum of ferrocene showed four absorptions at $240(\varepsilon 3,500), 265(\varepsilon 1,600) .325(\varepsilon 50)$ and $440(\varepsilon 102) \mathrm{nm}$. which are well matched to those in the literature.$^{-1}$ Two major absorption maxima presumably originated from the $\pi-\pi^{*}$ transition were observed in the regions of 223 257 and $267-310 \mathrm{~nm}$ and two minor absorptions from ferrocene moiety in the regions of $325-370$ and $440-460 \mathrm{~nm}$. The absorption maximum is highly dependent on the nature of the heterocycles attached to ferrocene. Absorptions at $238 \mathrm{~nm}$ for 3a and $231 \mathrm{rm}$ of $3 \mathbf{b}$ as well as absorptions at $268 \mathrm{~nm}$ for $3 \mathbf{a}$ and $267 \mathrm{~nm}$ for 3b were shifted bathochromatically ( $20 \mathrm{~nm}$ and 33 num, respectively) in $3 c$. in which the conjugation was extended by benzo-annulation. Such an extension of the conjugation additionally was also resolved absorptions at 223 and $252 \mathrm{~nm}$ of $3 \mathrm{c}$ and absorptions in the region of $290-416 \mathrm{~nm}$. UV absorption spectnum of ferrocene is characteristic to show two weak absorption maxima at 325 and $440 \mathrm{~nm}^{3]}$ and are. thus, tentatively assigned as an intramolecular charge transfer absorption involving promotion of iron $d$ orbitals to ring $\pi$ orbitals of ferrocene moiety ${ }^{\text {ta }}$ Although both the position and the intensity of the $440 \mathrm{~nm}$ band are claimed to be particularly sensitive to ferrocene ring-tilt distortion, ${ }^{73} \mathrm{UV}$ spectra of the present system did not afford any clear evidence for the geometry.

Emission spectra of the compounds prepared were measured in $\mathrm{EtOH}\left(6.25 \times 10^{-5} \mathrm{M}\right)$ and the data were summarized in Table 2 . All the ligands could be well excited to show good
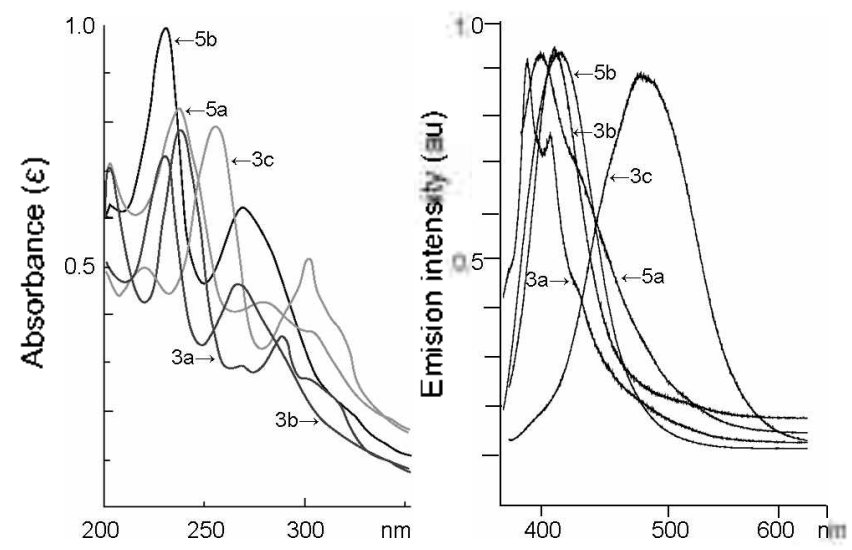

Figure 2. UV absorption and emission spectra of heteroarylierrocenes in $95 \% \mathrm{EtOH}$. UV spectrum of ferrocene was omitted for clarity.

emissions. The șistem with a benzo[h]quinoline ring showed three enission wavelengths of 396.420 . and $4+0$ (sh) $\mathrm{nm}$ while with two benzo[ $h$ ]quinoline rings 408 and 440 (sh) $\mathrm{mm}$. respectively. The compounds with mono- and di-1.10-phenanthrolines showed only one emission at 420 and $+25 \mathrm{~nm}$, respectively and a system with benzo[b]-1,10-phenanthroline gave a green light emission at $510 \mathrm{~nm}$ with $100 \mathrm{~mm}$ of a full width at half max. The observed emission wavelength is highly dependent on the nature of the heterocycles. Each of the enission maxima is bathochromatically slifted from benzo $[h]$ quinoline ring to benzo $[b]-1,10$-phenanthroline ring indicating that more planar ligand emits the lower energy.

\section{Conclusions}

A series of mono- and 1.l'-bis(heteroaryl)-substituted ferro- 
cenes were prepared by employing Frielander reaction of acetyland 1.1 '-diacety lferrocene with a series of $o$-aminoaldehydes. Reactions of 1.1 '-diacetylferrocene with two equivalents of 1-aminonaphthalene-2-carbaldehyde and 8-aminoquinoline7-carbaldehyde afforded a mixture of mono- and 1.1'-bis(heteroaryl)-substituted ferrocenes in a ratio of $1: 3.1-3.8$. while the reaction with 4 -aminoacridine-3-carbaldehyde did not provide any characterizable product presumably due to the redox instability of the product induced by low reduction potential of benzo[b]-1.10-phenanthroline. Stnictures of the compounds could be deduced from ${ }^{l} \mathrm{H}$ NMR data to show that two heteroaromatics are not only in coplanarity of heteroaryl ring(s) with cyclopentadienyl ring but also are in sw geometry around ferrocene moiety and pointing in opposite direction with their py ridine moieties partially overlapped. Two major absorption maxima presumably originated from the $\pi \cdot \pi^{*}$ transition were observed in the regions of $223-257$ and $267-310 \mathrm{~nm}$ and two minor absorptions from ferrocene moiety in the regions of 325 370 and $447 \mathrm{~nm}$. All the ligands showed good emissions to give three emission wavelengths of 396.420 , and 440 (sh) $\mathrm{nm}$ for mono benzo $[h]$ quinoline ring sy stem comparable to those (408 and $440 \mathrm{~nm}$ ) of two benzo[ $h$ ]quinoline rings. The compounds with mono- and di-1.10-phenanthrolines showed only one emission at +20 and $+25 \mathrm{~nm}$. respectively and a system with benzo $[b]-1.10$-phenanthroline gave green light emission at $510 \mathrm{~nm}$

Supporting Infommation. 'H NMR spectra $(600 \mathrm{MHz})$ of 1.1'-bis( 1. 10-phenanthrolin-2'-yl)ferrocene (5b) are available on request from the correspondence author.

Acknow ledgments. WЛ and JMC are recipients of BK-21 scholarship (2008). Obtaining emission spectra as well as helpful discussion bỵ Dr. A. F. M. M. Rahman is also gratefully acknowledged.

\section{References and Notes}

1. (a) Kealy, T. J.; Pauson, P. I. Nantre 1951, 168, 1039. (b) Miller, S. A.: Tebboth, T. A.: Tremaine, T. F. J. Chem. Soc. 1952, 632.

2. Wilkinson, G.: Rosenblum, M.: Whiting, M. C.: Woodward, R. B. J. Am Chem Soc. 1952, 74, 2125. (b) Rosenblum, M.: Whiting, M. C.: Woodward, R. B. J. Am. Chem. Soc. 1952, 74, 3458 .

3. (a) Holm, C. H.; Ibers, J. A. J. Chem. Phys. 1959, 30, 885 (b) Mulav, L. N.; Attalla, A. J. Am. Chem. Soc. 1963, 85, 702.

4. (a) Shimizu, I.; Kamei, Y.; Tezuka, T.; Izumi, T.: Kasahara, A. Bull Chem. Soc. Jpn. 1983, 56, 192. (b) Shinizu, I.; Unezawa, H.; Kanno, T.; Izumi, T.; Kasahara, A. Bull. Chem. Soc. Jpn. 1983, 56, 2023. (c) Kasaha, A.: Inuni, T.: Shimiilı, I.; Oikawa, T.;
Umezawa, H.: Murakami, M.; Watanabe, O. Bull. Chem. Soc. Jpm. 1985, 58, 1560 .

5. Gelin, F.: Thummel, R. P. J. Org. Chem 1992, 57,3780.

6. Fuchs, B.; Frohlich, R.; Musso, H. Chent Ben. 1986, 118, 1968.

7. (a) Atkinson, R. C. J.; Gibson, V. C.; Long, N. T. Chent Soc: Rev: 2004, 33,313 . (b) Constable, E. C. Angew. Chem. Int Ed. Engl. $1991,30,407$.

8. (a) Chen, C.-G.; Hou, X.-L.; Pu, L. Org. Lett. 2009, 11, 2073. (b) Ogasawara, M.: Watanabe, S.; Nakajima, K.: Takahashi, T. Pue Appl. Chent 2008, 80, 1109.

9. (a) Fenocenes: Homogenons Catalysis - Organic Symhesis Matenal Science; Togni, A.; Hayashi, T., Eds.: VCH: Weinheim, Gemany, 1995. (b) Beer, P. D.; Hayes, E. J. Coort. Chent. Rev. 2003, 240, 167. (c) Hong, J. H.; Bui, N. N.: Mho, S. I.; Cho, W. S.: Jang, H. Y. Bull. Kor: Chem. Soc. 2008, 29, 2097.

10. Utepova, I. A; Chupakhin, O. N.; Charushin, V. N. Heterocycles 2008, 76, 39.

11. (a) Chea, I. M.; Tahng, Y. Heterocycles 2009, 78, 1573 . (b) Rahman, A. F. M. M, Jahug, Y. Heterocycles 2008, 75, 2507, and reterences therein

12. (a) Opie, J. W.; Smith, L. I. Org. Syn. Col. Iol. III 1955, 56. (b) Majewicz, G.; Caluwe, O. A.J. Org. Chem. 1974, 39, 720. (c) Hung, C.-Y.; Wang, T.-L.; Shi, Z.: Thummel, R. P. Tetrahedron 1994, 50, 10685. (d) Riesgo, E. C.; Jin, X.; Thummel, R. P. J. Org. Chem. 1996, 61, 3017. (e) Son, J. K.; Son, J. K.; Jalung, Y. Heterocycles 2002, 57,1109 .

13. Commercially available: we employed acetylterrocene and 1,1 'diacetylterrocene from Lancaster Chemical Company.

14. Rosenblum, M.; Woodward, R. B. J. Am. Chem. Soc, 1958, 80 , 5443.

15. Recent example of base-catalyzed deacetylation of heteroaromatics: (a) Rahman, A. F. M. M.; Kwon, Y.. Jahng. Y. Heterocyctes 2005, 65, 2777. (b) Attanasi, O. A.; Filippone, P; Fionucci, C.: Foresti. E.: Mantellini. F. J. Org. Chem. 1998. 63.9880. Strong alkali-catalyzed predeacety lation of 2,4-pentanedione to acetone was also reported, see: Stetanovic, G.; Lorenc, P.-W. M: Lorenc, L.: Mihailovic, M. L. Tetrahedron 1959, 6,97. Examples of base-catalyzed deacetylation of acylacetone to methy l ketone: a) Fischer, F.; Bülow, C. Ber. 1885, 18, 2132. b) Connor, R: Adkins, H. J. Am. Chem. Soc. 1932, 5t, 3420 .

16. Tabner, B. . .: Yandle, J. R. J. Chem. Soc. 1968, 381.

17. Jahug, Y; Park, T. G.; Yu, T. W. Bull. Kon, Chem. Soc. 2000, 21, 333

18. (a) Butler, I. R.; Roustan, T.-L. Com. J. Chem. $1990,68,2212$. (b) Chupakhin, O. N.; Utepova, I. A.; Kovvalev, I. S.: Rusonov, V. L.: Starikova, Z. A. Em.J. Org. Chem. 2007, 857.

19. (a) Koft, E.; Case, F. H. J. Ong. Chen 1962, 27,865. (b) Motiur, A. F. M.: Kwon, Y. J.: Jahng, Y. Heterocucles 2005, 65, 2777.

20. Pretsch, E. T.; Seibl, W.: Simon: Clerc, T. Tables of Spectral Data for Structure Detemination of Organic Compounds. ${ }^{13} \mathrm{C}-\mathrm{A} \Omega R$, ${ }^{2} H$ M M R IR, MS, and LF.TIS - Chemical Laboraton Practice, $2^{\text {nd }}$ Ed:; Springer-Verlag: Berlin Heidelberg, 1989.

21. (a) Rosenblum, M. Chemistw of The Iron Group Metallocenes: Interscience Publishers: New York, 1965; Part 1, p. 42 (b) Nielson. D.: Famer, M.: Evring. H. J. Phys Chent 1976, 80,717.

22. Jaffe, H. H. J. Chem. Phys. 1953, $21,156$.

23. Barr, T. H.; Watts, W. E. J. Organomet Chem. 1968, 15. 177. 